\title{
PENGARUH PEMBERIAN SMOOTHIE ALPUKAT TERHADAP KADAR KOLESTEROL PADA WANITA MENOPAUSE DI KELAS LANSIA
}

\author{
Rosalia N.H Lamanepa, S.Tr.Keb \\ Miftakhul Mualimah, SST., M.Kes \\ Prodi Kebidanan (D.IV), \\ Fakultas IImu Kesehatan, Universitas Kadiri
}

\begin{abstract}
ABSTRAK
Kolesterol menjadi ujung pangkal permasalahan munculnya berbagai penyakit dalam tubuh. Ada banyak cara yang dapat dilakukan untuk menangani kadar kolesterol, selain perawatan medis, pengobatan tradisional juga bisa dilakukan untuk mencegah dan menurunkan kadar kolesterol yang tinggi diantaranya buah alpukat. Penelitian ini bertujuan untuk mengetahui pengaruh pemberian smoothie alpukat terhadap kadar kolesterol pada wanita menopause di kelas lansia BPM Ny "N". Penelitian ini termasuk penelitian pre eksperimen dengan pendekatan One Group Pretest-Posttest Design.

Populasi dalam penelitian ini adalah semua wanita menopause yang mengalami hiperkolesterolemia (kolesterol $>200 \mathrm{mg} / \mathrm{dL}$ ) di Kelas Lansia BPM Ny "N" sebanyak 30 orang. Dengan sampel sebanyak 16 orang. Teknik sampel yang digunakan adalah purposive sampling. Hasil penelitian menunjukkan adanya pengaruh pemberian smoothie alpukat terhadap kadar kolesterol pada wanita menopause di kelas lansia BPM Ny "N" dengan persentase penurunan rata-rata kolesterol sebanyak $16.14 \%$. Uji statistik menggunakan Uji T berpasangan dengan tingkat kepercayaan 95\% didapatkan $p$-value $<\alpha$ yaitu $0.000<0.05$ yang artinya ada perbedaan signifikan antara kadar kolesterol sebelum dan sesudah mengkonsumsi smoothie alpukat pada wanita menopause.

Dari hasil penelitian ini dapat disimpulkan bahwa smoothie alpukat efektif menurunkan kadar kolesterol pada wanita menopause dan dari hasil penelitian ini diharapkan masyarakat dapat menggunakan smoothie alpukat sebagai salah satu alternatif terapi untuk menurunkan kolesterol pada wanita menopause.
\end{abstract}

Kata Kunci: Smoothie Alpukat, Kadar Kolesterol, Menopause

\section{ABSTRACT}

Cholesterol becomes the root of the problem of the emergence of various diseases in the body. There are many ways that can be done to handle cholesterol levels, in addition to medical care, traditional medicine can also be done to prevent and lower high cholesterol levels such as avocados. This study aims to determine the effect of avocado smoothie on cholesterol levels in menopausal women in the elderly BPM Ny " $N$ " class. This research includes pre experimental research with One Group Pretest-Posttest Design approach.

The population in this study were all menopausal women who had hypercholesterolaemia (cholesterol> 200mg / dL) in the elderly grade BPM Ny " $N$ " as many as 30 people. With a sample of 16 people. The sample technique used is purposive sampling. The research instrument used was monitor cholesterol and observation sheet. The results showed the effect of giving avocado smoothie to cholesterol levels in menopausal women in the elderly class BPM $N y$ " $N$ " with the percentage decrease in average cholesterol as much as $16.14 \%$. Statistical test using paired T Test with 95\% confidence level obtained $p$-value $<\alpha$ that is $0.000<0.05$ which means $\mathrm{HO}$ rejected and $\mathrm{H} 1$ accepted.

This means there is a significant difference between cholesterol levels before and after consuming avocado smoothie in menopausal women in the Elderly Class BPM Ny " $\mathrm{N}$ ". From the results of this study is expected people can use avocado smoothie as one alternative therapy to lower cholesterol in menopausal women.

Keywords: Avocado Smoothie, Cholesterol Level, Menopause 


\section{PENDAHULUAN}

Kolesterol sangat erat kaitannya dengan kesehatan jantung dan pembuluh darah. Akibat pola makan dan pola hidup yang salah, banyak orang menghadapi masalah kesehatan karena tingginya kadar kolesterol dalam darah. Sering kali masyarakat kurang memperhatikan pola hidup, seperti makan makanan yang banyak mengandung lemak jenuh (LDL) seperti makanan yang digoreng, jeroan dan daging sudah menjadi kebiasaan mereka ditambah lagi dengan kurangnya aktifitas fisik ataupun pola hidup pasif (Sedentary Life Style) akan memperbanyak timbunan lemak dalam tubuh. Hal ini didukung dengan fasilitas yang semakin maju, makanan cepat saji (fast food) yang semakin merambah dan kesibukan sehari-hari sehingga hanya mengandalkan pola hidup yang serba praktis (Anies,2015).

Salah satu penyakit yang disebabkan oleh kolesterol adalah hiperlipidemia. Hiperlipidemia adalah tingginya kadar lemak (kolesterol, trigliserida atau keduanya) dalam darah. Kadar lemak yang abnormal dalam sirkulasi darah (terutama kolesterol) bisa menyebabkan masalah jangka panjang. Resiko terjadinya aterosklerosis dan penyakit arteri koroner atau arteri karotis meningkat pada seseorang yang memiliki kadar kolesterol yang tinggi. Dengan kadar kolesterol yang tinggi akan memacu banyaknya LDL (kolesterol jahat) yang dapat menghambat peredaran darah dan menyebabkan penyumbatan pembuluh darah dan lebih fatal lagi menyebabkan penyakit jantung koroner. Kadar kolesterol yang rendah biasanya baik dibandingkan kadar kolesterol tingggi, tetapi kadar yang terlalu rendah juga tidak baik. Kadar kolesterol total yang ideal adalah $200 \mathrm{mg} / \mathrm{dL}$ atau kurang. Jika kadar kolesterol total mendekati 300 $\mathrm{mg} / \mathrm{dL}$, maka resiko terjadinya serangan jantung adalah lebih dari 2 kali (Mardalena, Ida. 2017).

Secara global PTM penyebab kematian nomor satu setiap tahunnya adalah penyakit kardiovaskuler. Penyakit kardiovaskuler adalah penyakit yang disebabkan gangguan fungsi jantung dan pembuluh darah seperti: Penyakit Jantung Koroner, Penyakit Gagal Jantung atau Payah Jantung, Hipertensi dan Stroke. Pada tahun 2008 diperkirakan sebanyak 17,3 juta kematian disebabkan oleh penyakit kardiovaskuler. Lebih dari 3 juta kematian tersebut terjadi sebelum usia 60 tahun dan seharusnya dapat dicegah. Kematian "dini" yang disebabkan oleh penyakit jantung terjadi berkisar sebesar $4 \%$ di negara berpenghasilan tinggi sampai dengan $42 \%$ terjadi di negara berpenghasilan rendah. Kematian yang disebabkan oleh penyakit kardiovaskuler, terutama penyakit jantung koroner dan stroke diperkirakan akan terus meningkat mencapai 23,3 juta kematian pada tahun 2030 (Pusat Data dan Informasi Kementrian Kesehatan RI, 2014).

Berdasarkan diagnosis dokter, prevalensi penyakit jantung koroner di Indonesia tahun 2013 sebesar $0,5 \%$ atau diperkirakan sekitar 883.447 orang, sedangkan berdasarkan diagnosis dokter/gejala sebesar $1,5 \%$ atau diperkirakan sekitar 2.650 .340 orang. Berdasarkan diagnosis/gejala, estimasi jumlah penderita penyakit jantung koroner di Provinsi Jawa Timur sebanyak 375.127 orang (1,3\%) (Pusat Data dan Informasi Kementrian Kesehatan RI, 2014). Sedangkan menurut survey awal yang dilakukan di kelas lansia BPM Ny "N" Kelurahan Bujel Kecamatan Mojoroto Kota Kediri terdapat 30 orang wanita menopause yang memiliki hiperkolesterolemia (kadar kolesterol $>200 \mathrm{mg} / \mathrm{dl}$ ). Menurut wawancara singkat yang dilakukan peneliti kepada bidan di BPM tersebut diketahui bahwa pasien hanya memeriksakan kolesterol jika dianjurkan oleh dokter. Dari hasil wawancara singkat, dari 10 orang wanita menopause yang mengalami hiperkolesterolemia ada 2 orang yang mengkonsumsi obat kolesterol sementara 8 orang lainnya tidak mengkonsumsi obatobatan dan hanya dianjurkan untuk mengubah pola hidup dan menjaga asupan makanan yang dikonsumsi, mereka juga jarang mengkonsumsi buah alpukat dan tidak mengetahui alpukat dapat menurunkan kadar kolesterol.

Pada umumnya penyakit kolesterol adalah penyakit ketika usia semakin bertambah lanjut ketika makanan yang masuk ke dalam tubuh bisa saja membawa penyakit. Tetapi dewasa ini penyakit kolesterol sepertinya sudah tidak memandang bulu lagi, para kawula muda pun bisa saja mengidap penyakit kolesterol, hal tersebut disebabkan karena tidak adanya batasan untuk mengkonsumsi makanan tanpa 
memperdulikan gizi yang terkandung di dalam makanan tersebut, kebiasaan dalam mengkonsumsi makanan cepat saji. Kolesterol menjadi ujung pangkal permasalahan munculnya berbagai penyakit dalam tubuh (Amanda,Rianti 2012). Jika pola hidup yang salah dikombinasikan dengan faktor-faktor genetik yang bisa menyebabkan persoalan kolesterol, proses terbentuknya artherosclerosis seolah-olah dipercepat. Keadaan ini potensial meningkatkan terjadinya penyakit kardiovaskuler pada usia dewasa. Sebelum usia menopause, wanita mempunyai kadar kolesterol total yang lebih rendah daripada pria dengan usia yang sama. Setelah menopause, kadar kolesterol LDL pada wanita cenderung meningkat (Bangun, 2012).

Ada banyak cara yang dapat dilakukan untuk menangani kadar kolesterol berlebih dalam tubuh. Selain perawatan medis, pengobatan tradisional juga bisa dilakukan untuk mencegah dan menurunkan kadar kolesterol yang tinggi. Selain itu pengobatan tradisional juga lebih ekonomis dan lebih mudah diperoleh, diantaranya buah alpukat, buah belimbing, buah mengkudu, buah delima, dan buah apel (Hembing, 2013). Buah alpukat adalah sumber lemak tidak jenuh yang bisa meningkatkan level HDL (Rahmawati, Sita. 2013). Alpukat merupakan salah satu bahan alami yang dapat membantu menurunkan kadar kolesterol LDL dan menaikkan kadar kolesterol HDL, sehingga secara nyata menurunkan kadar kolesterol total. Alpukat mengandung beberapa bahan aktif yang diduga dapat menurunkan kadar kolesterol dalam darah, antara lain: niacin (vitamin B3), $\beta$-sitosterol, vitamin C, asam pantothenat, asam oleat, golongan MUFA, asam folat, selenium, asam amino dan serat (Anggraheny, Dewi 2013).

Berdasarkan penelitian yang telah dilakukan oleh Anggraheny (2013) untuk mengetahui efek pemberian jus alpukat dalam menurunkan kadar kolesterol total serum yang dilakukan pada tikus jantan galur wistar hiperlipidemia. Penelitian ini dilakukan selama 15 hari, menggunakan 8 ekor tikus dengan BB 200gr. Tikus tersebut dibagi dapat 4 kelompok dimana 1 kelompok sebagai kelompok kontrol sedangkan 3 kelompuk lain sebagai kelompok perlakuan yang diberikan jus alpukat sebagai masing-masing $2 \mathrm{ml}, 3 \mathrm{ml}$ dan $4 \mathrm{ml}$. Hasil penelitiannya menunjukan bahwa pemberian jus aplukat dengan dosis 2 $\mathrm{ml} /$ hari, $3 \mathrm{ml} /$ hari dan $4 \mathrm{ml} /$ hari selama 15 hari pada tikus wistar jantan hiperlipidemia terbukti mampu menurunkan kadar kolesterol total serum secara bermakna dengan penurunan kadar kolesterol total serum yang paling tinggi didapatkan pada tikus yang diberi perlakuan dosis 4ml/hari (Anggraheny, Dewi 2013). Berdasarkan uraian diatas, maka peneliti tertarik untuk melakukan penelitian dengan judul Pengaruh Pemberian Smoothie Alpukat Terhadap Kadar Kolesterol Pada Wanita Menopause Di Kelas Lansia.

\section{METODE PENELITIAN}

Penelitian pre eksperimen dengan menggunakan one group pre test dan post test desain. Penelitian dilakukan di PBM Ny. "N" Kelurahan Bujel Kecamatan Mojoroto Kota Kediri pada bulan Januari 2018. Dalam penelitian ini terdapat variabel independen yaitu pemberian smoothie alpukat, serta variabel dependen yaitu kadar kolesterol pada wanita menopause. Sampel dalam penelitian ini yaitu 16 ibu lansia yang berada di kelas lansia di BPM Ny. "N" yang ditentukan dengan teknik purposive sampling. Instrumen dalam penelitian yaitu menggunakan kolesterol monitor, alat tulis, lembar inform consent dan peralatan untuk membuat smoothie alpukat. Data penelitian dianalisis dengan menggunakan uji wilcoxon.

\section{HASIL}

Data umum dan data khusus dalam penelitian, masing-masing akan dijelaskan secara lengkap sebagai berikut.

1. Data Umum Responden

Tabel 1. Distribusi Frekuensi Responden

\begin{tabular}{lrr}
\hline \multicolumn{1}{c}{ Variabel } & $\mathrm{N}=16$ & \multicolumn{1}{c}{$(\%)$} \\
\hline Pendidikan & & \\
\hline Dasar & 9 & 56,25 \\
Menengah & 5 & 31,25 \\
Perguruan Tinggi & 2 & 12,5 \\
\hline Pekerjaan & & \\
\hline Wiraswasta & 2 & 12,5 \\
PNS dan Pensiunan & 4 & 25 \\
lbu Rumah Tangga & 10 & 62,5 \\
\hline Kebiasaan Olahraga & & \\
\hline Rutin & 5 & 31,25 \\
Tidak Rutin & 11 & 68,75 \\
\hline Kebiasaan Makan & & \\
\hline Konsumsi buah dan & 7 & 43,75 \\
sayur & & \\
Lebih sering daging & 9 & 56,25 \\
dan bersantan & & \\
\hline
\end{tabular}


Berdasarkan tabel 1 dapat disimpulkan bahwa sebagian besar responden berpendidikan dasar $(56,25 \%)$, sebagai IRT $(62,5 \%)$, mempunyai kebiasaan tidak rutin olahraga $(68,75 \%)$, dan lebih sering konsumsi makanan bersantan dan daging $(56,25 \%)$.

2. Data Responden Sebelum diberikan smoothie alpukat

Tabel 2. Distribusi Frekuensi kadar kolesterol Responden Sebelum diberikan smoothie alpukat

\begin{tabular}{|c|c|c|c|c|c|}
\hline Variabel & Mean & Median & SD & Min & Max \\
\hline $\begin{array}{l}\text { Pre } \\
\text { Test }\end{array}$ & 275.25 & 271 & 46.832 & 224 & 399 \\
\hline $\begin{array}{l}\text { Bero } \\
\text { disimpulk } \\
\text { kolestero } \\
\text { dimana } \\
\text { sebesar }\end{array}$ & $\begin{array}{l}\text { lasarka } \\
\text { ran b } \\
\text { I lansic } \\
\text { nilai r } \\
<200 \mathrm{mb}\end{array}$ & $\begin{array}{l}\text { tabel } \\
\text { a rata } \\
\text { lasih di } \\
\text { nal koles }\end{array}$ & $\begin{array}{cc}2 & 0 \\
\text { rata } & k \\
\text { atas no } \\
\text { sterol ac }\end{array}$ & $\begin{array}{l}\text { apat } \\
\text { adar } \\
\text { mal, }\end{array}$ & \\
\hline
\end{tabular}

3. Data Responden Setelah Diberikan smoothie alpukat

Tabel 3. Distribusi kadar kolesterol setelah diberikan smoothie alpukat

\begin{tabular}{llllll}
\hline Variabel & Mean & Median & SD & Min & Max \\
Post & 230.81 & 211.5 & 42.584 & 161 & 305 \\
Test & & & & & \\
Hari Ke & & & & & \\
8 & & & & & \\
\hline
\end{tabular}

\section{8}

Berdasarkan tabel 3 dapat

disimpulkan bahwa rata rata kadar kolesterol lansia setelah pemberian smoothie alpukat sebesar 230,81, sehingga dapat disimpulkan kadar kolesterol mengalami penurunan sebesar $44.44 \mathrm{mg} / \mathrm{dl}(16.14 \%)$.

4. Pengaruh pemberian smoothie alpukat terhadap kadar kolesterol pada wanita menopause

Tabel 4. Analisa perbedaan kadar kolesterol sebelum dan sesudah diberikan smoothie alpukat

\begin{tabular}{|c|c|c|c|c|c|c|}
\hline Variabel & Mean & SD & $\mathrm{N}$ & Min & $\max$ & $\begin{array}{l}p \text { - Ditambah dengan kurangnya aktivitas fisik } \\
\text { value maka kemungkinan terjadinya penimbunan }\end{array}$ \\
\hline Pre Test & 275.25 & 46.832 & 16 & 224 & 399 & $\begin{array}{l}\text { akanan dalam bentuk lemak } \\
\text { ar. (Tisnadiaia.Diadiat 2012) }\end{array}$ \\
\hline $\begin{array}{l}\text { Post Test } \\
\text { Hari ke } 8\end{array}$ & 230.81 & 42.584 & 16 & 161 & 305 & ori salah satu cara \\
\hline Penurunan & 44.44 & & & & & an mengubah pola makan. Dir \\
\hline
\end{tabular}

Berdasarkan tabel 4, hasil analisis statistik dengan tingkat kepercayaan 95\% hasil uji statistik menggunakan $\mathrm{Uji} T$ berpasangan didapatkan $p$-value $<\alpha$ yaitu $0.000<0.05$ menunjukkan bahwa $\mathrm{H}_{0}$ ditolak dan $\mathrm{H}_{1}$ diterima yang artinya ada perbedaan signifikan antara kadar kolesterol sebelum dan sesudah mengkonsumsi smoothie alpukat pada wanita menopause.

\section{PEMBAHASAN}

\section{Kadar Kolesterol Sebelum diberikan Smoothie Alpukat Pada Menopause di Kelas Lansia}

Berdasarkan hasil penelitian yang dilakukan pada wanita menopause di Kelas Lansia diketahui rata-rata kadar kolesterolnya adalah $275.25 \mathrm{mg} / \mathrm{dl}$. Beberapa ahli berpendapat bahwa kenaikkan LDL seiring bertambahnya usia berhubungan dengan makin berkurangnya kemampuan aktivitas LDL reseptor.

Pada usia produktif perempuan dilindungi oleh estrogen dari masalah atherosklerosis. Estrogen dipercaya dapat mencegah terbentuknya plak pada arteri dengan meningkatkan HDL dan menurunkan LDL pada darah. Namun setelah menopasue dimana tingkat estrogen pada perempuan menurun resiko atherosklerosis akan meningkat pada wanita menopause (Tisnadjaja,Djadjat 2012).

Pendidikan tidak berkaitan langsung dengan kejadian hiperkolesterolemia pada wanita menopause, namun masalah gizi timbul karena ketidaktahuan atau kurangnya informasi tentang gizi yang memadai. Penelitian Ayuandrura,Aulia membuktikan bahwa semakin tinggi tingkat pendidikan seseorang, maka pengetahuan tentang gizi dan kepedulian terhadap jenis makanan yang sehat dan bergizi juga akan meningkat (Ayuandrura,Aulia, 2012).

Selain itu, bila pola makan banyak mengkonsumsi daging, apalagi jeroan maka kemungkinan menderita hiperkolesterolemia akan lebih besar. 
dianjurkan karena berfungsi untuk mengikat lemak yang berasal dari makanan dalam proses pencernaan, sehingga mencegah peningkatan kadal LDL kolesterol. (Brata,Wisnu, 2010).

\section{Kadar Kolesterol Sesudah diberikan Smoothie Alpukat Pada Menopause di Kelas Lansia}

Berdasarkan hasil penelitian, kadar kolesterol pada wanita menopause pada pemberian smoothie alpukat hari keempat rata-ratanya $260.9 \mathrm{mg} / \mathrm{dl}$, lalu di periksa lagi pada hari ke delapan dengan rata rata 230.8 $\mathrm{mg} / \mathrm{dl}$. Dimana rata-rata penurunan kadar kolesterol selama pemberian 1 minggu smoothie alpukat sebanyak $44.44 \mathrm{mg} / \mathrm{dl}$.

Hal ini disebabkan karena daging alpukat mengandung zat yang dapat menurunkan kadar kolestrol. Dalam daging alpukat mengandung asam pantothenat (vitamin B5) dan asam folat vitamin B3 (niacin), vitamin $C$ dan asam lemak tak jenuh tunggal (monounsaturated fatty acid/MUFA) (Rahman,Shahrul 2016).

Dalam daging buah alpukat kandungan yang paling mempengaruhi penurunan kadar kolesterol adalah asam lemak tak jenuh tunggal (Monounsaturated Fatty Acid/MUFA) dilihat dari kandungan MUFAlah yang paling besar jumlahnya yakni sebesar 9.8 gram dan serat sebanyak 6.7 gram per $100 \mathrm{gr}$ daging buah alpukat.

\section{Analisis Pemberian Smoothie Alpukat Terhadap Kadar Kolesterol Pada Menopause}

Berdasarkan tabel 4 dapat dilihat bahwa sebelum diberikan smoothie alpukat nilai rata-rata kadar kolesterol responden adalah $275.25 \mathrm{mg} / \mathrm{dl}$. Dan setelah diberikan smoothie alpukat kadar kolesterol responden mengalami penurunan menjadi $260,88 \mathrm{mg} / \mathrm{dl}$ dan pada hari hari kedelapan, kadar kolesterol mengalami penurunan menjadi $230.81 \mathrm{mg} / \mathrm{dl}$ sehingga prosentase penurunan sebelum dan sesudah adalah $16.14 \%$.

Berdasarkan Hasil analisis statistik uji T berpasangan menunjukan nilai sig (2-tailed) $p$-value 0.000 dengan nilai $\alpha 0.05$ berarti nilai $p$-value < nilai $\alpha$, maka $\mathrm{H}_{0}$ ditolak dan $\mathrm{H}_{1}$ diterima. Artinya ada pengaruh konsumsi Smoothie alpukat terhadap kadar kolesterol pada wanita menopause.
Dari data tersebut diketahui bahwa dibandingkan hasil pemeriksaan pada hari keempat, penurunan kadar kolesterol lebih besar terjadi pada pemeriksaan pada hari kedelapan. Hal ini menunjukkan bahwa lama waktu mengkonsumsi smoothie alpukat menjadi salah satu faktor yang menentukan seberapa banyak nilai kadar kolesterol seseorang mengalami penurunan. Hal ini sesuai dengan hasil penelitian Usman,Meutia tentang pengaruh konsumsi buah alpukat terhadap kadar kolesterol total pada pasien hiperkolesterol menunjukan bahwa dengan pemberian jus alpukat secara rutin terbukti dapat menurunkan kadar kolesterol (Usman, Meutia 2013). Dimana dalam sekali mengkonsumsi smoothie alpukat didalamnya terdapat $17.248 \mathrm{gr}$ asam pantothenat dari Gol. MUFA dan $11.792 \mathrm{gr}$ serat dimana sesuai dengan teori yang telah dibahas diatas kedua kandungan alpukat inilah yang paling berpengaruh dalam membantu penurunan kadar kolesterol seseorang.

\section{KESIMPULAN}

1. Kadar kolesterol wanita menopause sebelum mengkonsumsi smoothie alpukat adalah $275.25 \mathrm{mg} / \mathrm{dl}$.

2. Kadar kolesterol wanita menopause setelah mengkonsumsi smoothie alpukat adalah $230.81 \mathrm{mg} / \mathrm{dl}$.

3. Adanya pengaruh pemberian smoothie alpukat terhadap kadar kolesterol pada wanita menopause di kelas lansia dengan nilai $p$-value 0.000 .

\section{SARAN}

Setelah mengetahui hasil penelitian ini diharapkan dapat memberikan pilihan alternatif pengobatan kepada ibu menopause yang mempunyai kadar kolesterol tinggi tanpa harus konsumsi obat obatan.

\section{DAFTAR PUSTAKA}

Amanda, Rianti (2012). Bebaskan Tubuh Anda Dari Kolesterol. Bandung: CV. P\&G Kilat Jaya

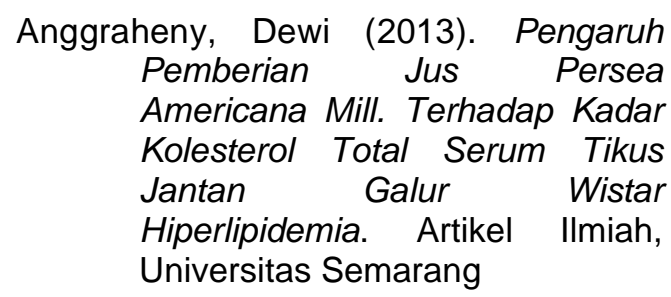


Rosalia N.H Lamanepa, S.Tr.Keb, Miftakhul Mualimah, SST., M.Kes, Pengaruh Pemberian Smoothie Alpukat Terhadap Kadar Kolesterol Pada Wanita Menopause Di Kelas Lansia

Arikunto, Suharsimi. 2003. Prosedur Penelitian, Suatu Praktek. Jakarta : Bina Aksara.

Ayuandira, Aulia. (2012). Hubungan Pola Konsumsi Makan, Status Gizi, Stres Kerja Dan Faktor Lain Dengan Hiperkolesterolemia Pada Karyawan PT Semen Padang Tahun 2012. Skripsi dipublikasikan: Fakultas Kesehatan Masyarakat Universitas Indonesia

Brata,Wisnu. (2010). Hubungan Pola Makan, Obesitas, Keteraturan Berolahraga Dan Kebiasaan Merokok Dengan Kejadian Hiperkolesterolemia. Skripsi dipublikasikan: Fakultas Kesehatan Masyarakat Universitas Muhammadiyah Semarang

Lusiana,Novita (2015). Buku Ajar Metodologi Penelitian Kebidanan. Yogyakarta: Deepublish

Mamat. (2013). Faktor-faktor yang berhubungan dengan kadar kolesterol HDL di Indonesia (Analisa Data Sekunder). Tesis dipulikasikan: Fakultas Kesehatan Masyarakat Universitas Indonesia

Mardalena, Ida. (2017). Dasar-Dasar IImu Gizi Dalam Keperawatan: Konsep Dan Penerapan Pada Asuhan Keperawatan. Yogyakarta: Pustaka Baru Press

Maulana,Mirza (2013). Penyakit jantung:Pengertian, Penanganan \& Pengobatan, Yogyakarta: Kata Hati

Notoatmodjo, S. 2010. Metodologi Penelitian Kesehatan. Jakarta : Rineka Cipta.

Pudiastuti,Ratna (2013). Penyakit Pemicu Stroke: Dilengkapi Dengan Posyandu Lansia Dan Posbindu PTM, Yogyakarta: Nuha Medika

Purwaningtyas, R.A (2016). Perbandingan Pemberian Susu Kedelai Dengan Jus Alpukat Terhadap Kadar Kolesterol Pada Anak Obesitas SD Negeri 1 Dan 2 Katerban Kutoarjo Purwerejo Jawa
Tengah. Naskah Publikasi, Universitas Aisyiyah

Pusat Data dan Informasi, (2014). Situasi Kesehatan Jantung: Mari Menuju Masa Muda Sehat, Hari Tua Nikmat Tanpa PTM Dengan Perilaku Cerdik, Jakarta: Kementerian Kesehatan RI

Rahmawati, Sita. (2013). Menu Sehat Kolesterol. Yogyakarta: Pustaka Insan Madani, Anggoya IKAPI

Sibagariang,Eva. (2016). Kesehatan Reproduksi Wanita: Edisi Revisi, Jakarta: Trans Info Media

Sulistyawati \& Proverawati. (2010). Menopause Dan Sindrom Pre Menopause, Yogyakarta: Nuha Medika

Tisnadjaja,Djadjat (2012). Bebas Kolesterol Dan Demam Berdarah Dengan Angak, Jakarta: Penebar Swadaya

Usman,Meutia. (2013). Pengaruh Konsumsi Buah Alpukat (Persea americana Mill) Terhadap Kadar Kolesterol Total Pada Pasien Hiperkolesterol di Puskesmas Padang Pasir Kota Padang. Skripsi dipublikasikan: Fakultas Kedokteran \& IImu Keperawatan Universitas Andalas. 